\title{
Induced ovulation of the first postpartum dominant follicle in beef suckler cows using a $\mathrm{GnRH}$ analogue
}

\author{
M. A. Crowe ${ }^{1}$, D. Goulding ${ }^{1 *}$, A. Baguisi $^{2}$, M. P. Boland ${ }^{2}$ and \\ J. F. Roche ${ }^{1}$ \\ ${ }^{1}$ Faculty of Veterinary Medicine, University College Dublin, Ballsbridge, Dublin 4, Ireland; and \\ ${ }^{2}$ Faculty of Agriculture, University College Dublin, Belfield, Dublin 4, Ireland
}

\begin{abstract}
There is a low incidence of ovulation of the first dominant follicle that develops in the early postpartum period of beef suckler cows, which prolongs the interval from calving to first ovulation. The objective of this study was to determine whether a single injection of a $\mathrm{GnRH}$ analogue would ovulate the first postpartum dominant follicle. Limousin $\times$ Friesian beef suckler cows were assigned at parturition, over two years (16 cows in year $1 ; 19$ cows in year 2), to one of three treatments: (1) untreated (control; $n=12$ ), (2) $\mathrm{GnRH}$ analogue $(20 \mu \mathrm{g}$ buserelin i.m.) administered in the growing-plateau phase of the first postpartum dominant follicle (GnRH-G; $n=12$ ) and (3) GnRH analogue administered in the declining phase of the first postpartum dominant follicle (GnRH-D; $n=11$ ). From day 8 or 9 post partum, the ovaries of each cow were examined daily by ultrasound to determine the time of $\mathrm{GnRH}$ injection and ovulation. Blood samples were collected daily for progesterone measurement to confirm ovulation and in year 2 to determine the duration of the first oestrous cycle. The mean ( \pm SEM) number of days from parturition to development of the first dominant follicle was $11.0 \pm 0.3,10.3 \pm 0.5$ and $10.1 \pm 0.7$ for cows assigned to treatments $1-3$, respectively $(P>0.05)$. The proportion of cows ovulating the first dominant follicle was higher $(P<0.05)$ following GnRH treatment ( 12 of 12 and 7 of 10; GnRH-G and GnRH-D, respectively) than with controls (2 of 12). The mean interval from parturition to first ovulation in all cows in the GnRH-G treatment was reduced (16.I \pm 0.8 days; $P<0.01$ ) compared with the interval for cows in the GnRH-D treatment (24.5 \pm 3.6 days) or controls ( $27.1 \pm 2.5$ days). There was no difference in the duration of the first luteal phase post partum in control $(9.3 \pm 3.0$ days) and GnRH-treated cows $(8.0 \pm 1.0$ and $9.6 \pm 3.7$ days; GnRH-G and GnRH-D, respectively) or in the proportion of cows with short cycles ( 4 of 7, 5 of 6 and 4 of 5; control, GnRH-G and GnRH-D, respectively). In conclusion, a single injection of $\mathrm{GnRH}$ analogue during the growing-plateau or declining phase of the first postpartum dominant follicle of beef suckler cows induced ovulation in most cows but did not alter the proportion of cows with short cycles compared with controls.
\end{abstract}

\section{Introduction}

Beef suckler cows have a longer postpartum anoestrous period than do dairy cows. Follicular growth resumes early after calving with the formation of the first dominant follicle, detected morphologically by ultrasound, within 10.2 days (Murphy et al., 1990). There is a low (11\%) incidence of ovulation of the first dominant follicle post partum (Murphy et al., 1990). This is in contrast to dairy cows, in which the first dominant follicle ovulated in more than $70 \%$ of cows (Savio et al., 1990). In beef suckler cows, there was recurrent growth and regression of dominant follicles with a mean of $3.2 \pm 0.2$ dominant follicles until first ovulation (Murphy et al., 1990). Thus, the prolonged anoestrous period in beef cows is due to a failure of ovulation *Present address: Dairygold A.I., Farms and Farm Services, Mallow, Co. Cork, Ireland.

Received 11 January 1993. of dominant follicles rather than a delay in development of dominant follicles.

This early resumption of follicular development in both beef and dairy cows is due to the rise in FSH concentrations after parturition (Schallenberger, 1985). Lack of ovulation of the early dominant follicle is hypothesized to be due to inadequate $\mathrm{LH}$ pulse frequency, which results in low androgen production in the follicle (Fortune, 1986) and inadequate oestradiol positive feedback to induce the LH surge (Peters et al., 1985). Factors affecting LH pulse frequency, such as suckling stimulus (Lamming et al., 1982; Myers et al., 1989), presence of the cow's own or an alien calf (Silveira and Williams, 1991), energy balance (Canfield and Butler, 1990) and body condition score of the cow (Wright et al., 1992), will therefore ultimately affect the time of first ovulation and the duration of the postpartum interval.

The administration of $\mathrm{LH}$ or GnRH will induce ovulation in a variety of species, including cattle, depending on the follicular 
status at the time of treatment. In dairy cows, Britt et al. (1974) showed that $\mathrm{GnRH}(100 \mu \mathrm{g}$ in an ear implant) during the early postpartum period could advance the time of first ovulation. A single injection of $\mathrm{GnRH}$ to postpartum anoestrous beef cows results in a significant rise in serum $\mathrm{LH}$ within $2 \mathrm{~h}$ of treatment (Wettemann et al., 1982). GnRH administration will therefore overcome the inadequate secretion of pituitary LH in the early postpartum period. However, in previous studies with beef cows, in which the follicular status at the time of GnRH administration was unknown, the ovulatory response was variable. Single injections of $\mathrm{GnRH}$ or an analogue induced ovulation in 18-93\% of cows (Fonseca et al., 1979; Mawhinney et al., 1979). Similar studies involving multiple injections of $\mathrm{GnRH}$ induced ovulation in 73-80\% (Riley et al., 1981; Walters et al., 1982) and $10-42 \%$ of cows (Edwards et al., 1983).

Because there is sequential development and atresia of dominant follicles in the majority of beef suckler cows before first ovulation, failure of some cows to ovulate following $\mathrm{GnRH}$ administration could be due to the state of development of the dominant follicle at the time of treatment. Our objective was therefore to determine whether the first postpartum dominant follicle, identified by ultrasound examination, could be ovulated using a single injection of a $\mathrm{GnRH}$ analogue. Specifically, we looked at the effect of administration of the $\mathrm{GnRH}$ analogue during either the growing-plateau phase of the first postpartum dominant follicle or the declining phase of the first postpartum dominant follicle. The growing-plateau phase, before emergence of a new wave of follicular growth, was selected to represent a physiologically active dominant follicle and the declining phase a dominant follicle undergoing atresia (Badinga et al., 1992).

\section{Materials and Methods}

\section{Animals and treatments}

The experiment was carried out over 2 years using 16 Limousin $\times$ Friesian cows in year 1 and 19 Limousin $\times$ Friesian cows in year 2. All cows calved in spring (April-May) and were in their second to fifth lactations. Cows were housed indoors up to calving and fed a maintenance diet of grass silage with a mineral supplement in year 1 and grass silage with barley straw ad libitum in year 2; after calving, the cows and calves were run at pasture. They were randomly assigned at calving each year to one of three treatments: (i) controls $(n=12)$; (ii) $20 \mu \mathrm{g}$ buserelin (Hoechst, Ireland, Ltd) administered (i.m.) during the growing-plateau phase of the first postpartum dominant follicle (GnRH-G; $n=12$ ) and (iii) $20 \mu \mathrm{g}$ buserelin administered (i.m.) during the declining phase of the first postpartum dominant follicle (GnRH-D; $n=11$ ).

Ovaries of cows were scanned daily from days 8 or 9 post partum to the time of first ovulation and formation of the corpus luteum was confirmed, using an ultrasound scanner (Dynamic Imaging, Livingston, Scotland) fitted with a $7.5 \mathrm{MHz}$ transrectal linear probe, as described previously (Murphy et al., 1990). A dominant follicle was defined as the largest follicle, $\geq 10 \mathrm{~mm}$ in diameter and at least $2 \mathrm{~mm}$ larger than other follicles present on either ovary, that suppressed the growth of other follicles. The growing-plateau phase of the first dominant follicle was defined as the time when the diameter of the dominant follicle increased in size or remained at the same value for two consecutive days and the declining phase was defined as the time when the diameter decreased by $\geq 3 \mathrm{~mm}$ over $\geq 2$ days. The experiment was terminated $4-5$ days after first ovulation in year 1 and either when first oestrus was detected or 25 days after first ovulation in year 2 . Blood samples were collected once a day throughout the experiment. Serum samples were obtained after centrifugation at $700 \mathrm{~g}$ for $20 \mathrm{~min}$, following storage at room temperature for $1 \mathrm{~h}$ and at $4^{\circ} \mathrm{C}$ for $18-24 \mathrm{~h}$; they were frozen at $-20^{\circ} \mathrm{C}$ until assayed for progesterone concentrations using the non-extraction radioimmunoassay described by Ronayne and Hynes (1990). The intra-assay coefficients of variation $(n=4)$ for samples containing 0.85 and $3.13 \mathrm{ng}$ progesterone $\mathrm{ml}^{-1}$ were 6.6 and $5.6 \%$, respectively. The interassay coefficients of variation $(n=9)$ for the same samples were 7.6 and $8.3 \%$, respectively. The sensitivity of the assay was $0.03 \mathrm{ng}$ progesterone $\mathrm{ml}^{-1}$. Progesterone concentrations were used to confirm the ultrasound results on timing of ovulation and corpus luteum formation. In year 2 , they were also used to determine the lifespan of the corpus luteum (defined as the interval between the first day serum progesterone was $\geq 0.3 \mathrm{ng} \mathrm{ml}^{-1}$ until the day serum progesterone decreased below $0.3 \mathrm{ng} \mathrm{ml}^{-1}$ ) after the first postpartum ovulation.

\section{Statistical analyses}

Data relating to intervals post partum and duration of the luteal phase were analysed using ANOVA (Snedecor and Cochran, 1980). Where significant differences occurred, specific differences between treatments were determined using Dunnett's $t$ test with a priori comparisons. Proportions of cows ovulating the first dominant follicle and numbers with short cycles after first ovulation were analysed using $\chi^{2}$ analysis.

\section{Results}

One of the 11 cows in the GnRH-D-treated group developed a luteinized follicle, after GnRH analogue treatment, which persisted for at least 29 days. At this stage, she was no longer monitored and was excluded from the analysis.

The mean $( \pm$ SEM $)$ number of days from parturition to development of the first dominant follicle was $11.0 \pm 0.3$, $10.3 \pm 0.5$ and $10.1 \pm 0.7$ for cows assigned to treatments $1-3$, respectively (Table 1 ). The proportion of cows ovulating the first postpartum dominant follicle was significantly higher $(P<0.05)$ following injection of the $\mathrm{GnRH}$ analogue (12 of 12 and 7 of 10 for GnRH-G-treated and GnRH-D-treated cows, respectively) than in controls ( 2 of 12 ; Table 1 ). In control cows, the mean ( \pm SEM) number of dominant follicles until first ovulation was $2.7 \pm 0.3$. The mean interval from parturition to first ovulation (Table 1) in GnRH-G-treated cows was significantly shorter ( $16.1 \pm 0.8$ days; $P<0.01$ ) than the interval for GnRH-D-treated ( $24.5 \pm 3.6$ days) or control cows $(27.1 \pm$ 2.5). However, the mean interval to first ovulation for GnRHD-treated cows was extended by three cows which failed to ovulate the first dominant follicle. In cows given the $\mathrm{GnRH}$ analogue (growing or declining phase), the mean interval to first ovulation for those that ovulated the first dominant follicle was Downloaded from Bioscientifica.com at 04/26/2023 07:37:57AM 
Table 1. The effect of administration of GnRH (buserelin) to postpartum beef suckler cows. The ovaries were scanned to identify the first dominant follicle postpartum, ovulation of the first dominant follicle, postpartum interval to first ovulation and duration of the first postpartum luteal phase. GnRH was administered either during the growing-plateau (GnRH-G) or declining $(\mathrm{GnRH}-\mathrm{D})$ phases of the first postpartum dominant follicle

Parameter Control GnRH-G GnRH-D

\begin{tabular}{lccc}
\hline Number of cows & 12 & 12 & 10 \\
PPI to first dominant follicle (days) & $11.0 \pm 0.3^{\mathrm{a}}$ & $10.3 \pm 0.5^{\mathrm{a}}$ & $10.1 \pm 0.7^{\mathrm{a}}$ \\
PPI to buserelin & - & $13.9 \pm 0.8$ & $15.6 \pm 0.7$ \\
Number ovulating first dominant follicle & $2^{\mathrm{a}}$ & $12^{\mathrm{b}}$ & $7^{\mathrm{b}}$ \\
PPI to first ovulation & $27.1 \pm 2.5^{\mathrm{a}}$ & $16.1 \pm 0.8^{\mathrm{b}}$ & $24.5 \pm 3.6^{\mathrm{a}}$ \\
Number of cows in year 2 & 7 & 6 & 5 \\
Number with short cycles & $4^{\mathrm{a}}$ & $5^{\mathrm{a}}$ & $4^{\mathrm{a}}$ \\
Duration of luteal phase $^{*}$ & $9.3 \pm 3.0^{\mathrm{a}}$ & $8.0 \pm 1.0^{\mathrm{a}}$ & $9.6 \pm 3.7^{\mathrm{a}}$
\end{tabular}

ab Values in a row with differing superscripts are significantly different $(P<0.05)$.

*Defined as the interval between the first day on which serum progesterone was $\geq 0.3 \mathrm{ng} \mathrm{ml}{ }^{-1}$ until the day on which serum progesterone decreased below $0.3 \mathrm{ng} \mathrm{ml}^{-1}$.

PPI: postpartum interval.
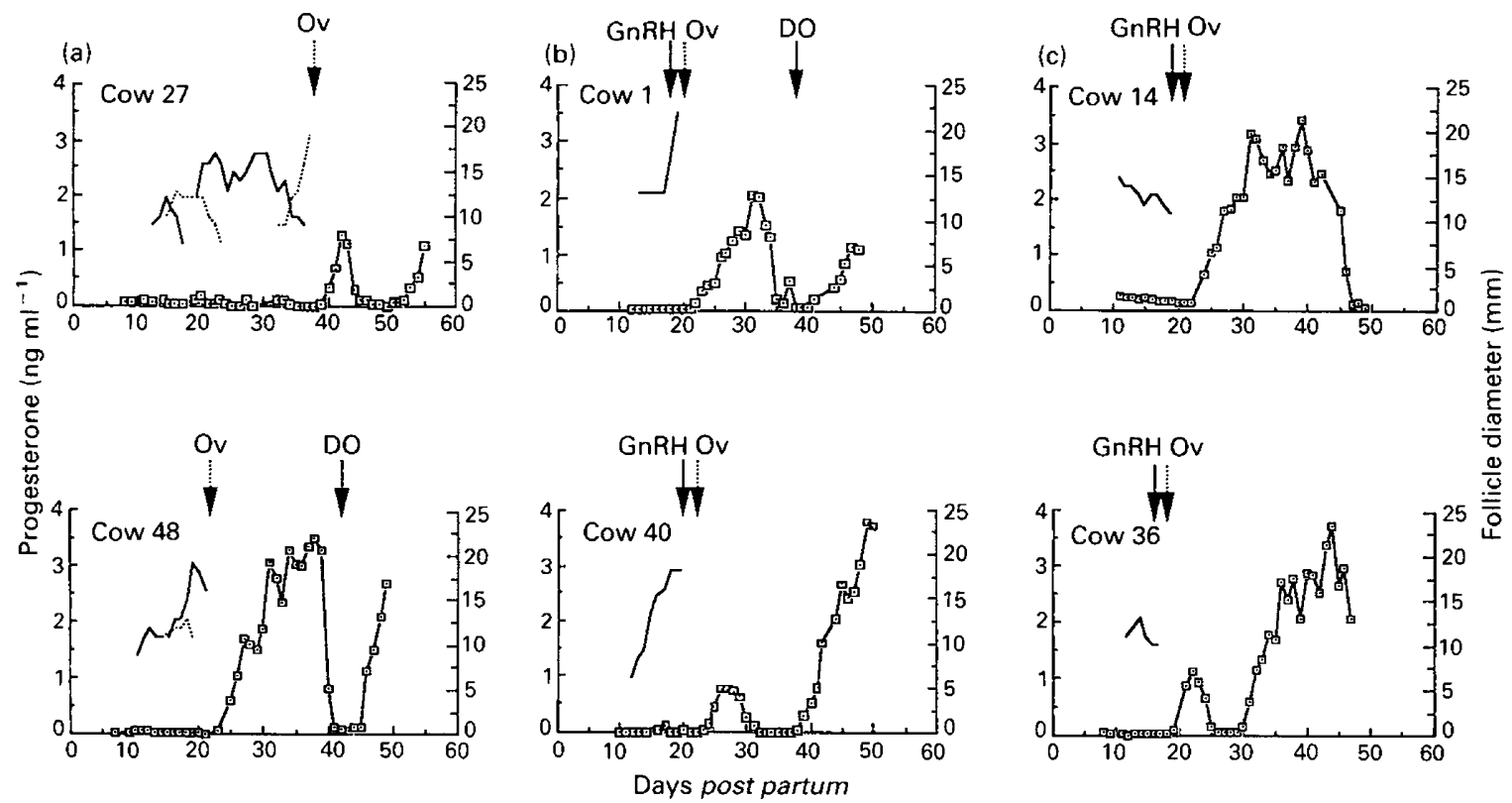

Fig. 1. Follicular development $(-; \cdots \cdots)$, times of $\mathrm{GnRH}$ treatment $(\mathrm{GnRH})$, ovulation $(\mathrm{Ov})$ and detected oestrus (DO), and progesterone profiles (- - - ) for two representative cows (year 2) from each treatment group: (a) controls, (b) $20 \mu \mathrm{g} \mathrm{GnRH}$ analogue administered in the growing phase of growth of the first postpartum dominant follicle and (c) $20 \mu \mathrm{g} \mathrm{GnRH}$ analogue administered in the declining phase of growth of the first postpartum dominant follicle.

$16.8 \pm 0.6$ days $(n=19)$ compared with $39.7 \pm 4.9$ days $(n=3)$ for those cows in which the first dominant follicle did not ovulate. Cows ovulating in response to the $\mathrm{GnRH}$ analogue were not detected in oestrus before ovulation.

The mean interval from ovulation to the first day on which serum progesterone concentrations increased above $0.3 \mathrm{ng} \mathrm{m}^{-1}$ was not different between treatments $(2.0 \pm 0.3,2.0 \pm 0.3$ and $2.0 \pm 0.2$ days; control, GnRH-G and GnRH-D, respectively; Fig. 1). In year 2 , there was no difference in the duration of the first luteal phase (all cows) post partum (Table 1) between control $(9.3 \pm 3.0$ days $)$ and GnRH-treated cows $(8.0 \pm 1.0$ and $9.6 \pm 3.7$ days; GnRH-G and GnRH-D, respectively) or in the proportion of cows with short cycles ( 4 of 7,5 of 6 and 4 of 5; control, GnRH-G and GnRH-D, respectively).

\section{Discussion}

The present data confirm the original finding that a dominant follicle develops within 10-15 days post partum in beef suckler cows, but the majority undergo atresia rather than ovulate (Murphy et al, 1990). However, the current results clearly show Downloaded from Bioscientifica.com at 04/26/2023 07:37:57AM 
that the first dominant follicle identified can ovulate following a single injection of the GnRH analogue. Previous work showed that GnRH treatment of postpartum beef cows results in a variable ovulatory response with $10-80 \%$ of treated cows ovulating after GnRH administration by single, multiple or pulsatile injections (Fonseca et al., 1979; Mawhinney et al., 1979; Riley et al., 1981; Walters et al., 1982; Edwards et al., 1983). In those studies, however, the follicular status at the time of $\mathrm{GnRH}$ administration was not known and this, together with various nutritional states, probably accounted for the poor and variable ovulatory responses obtained. Thus, the data reported here may help to explain the reported variable ovulatory response by showing that it is the presence of a growing or mature dominant follicle that is the key factor determining the success of $\mathrm{GnRH}$ treatment in inducing ovulation early in the postpartum period.

The formation of a dominant follicle early in the postpartum period suggests that FSH secretion is not deficient, but the failure of ovulation of the majority of the first dominant follicles implicates LH deficiency as the probable cause of anovulation. Gonadotrophin release is primarily controlled by binding of $\mathrm{GnRH}$ to specific receptors on the gonadotroph cells of the pituitary (Braden and Conn, 1991). GnRH evokes other cellular responses including the biosynthesis of $\mathrm{LH}$, as it stimulates the production of mRNA for the $\beta$ subunit (Braden and Conn, 1991). Ovulation of the first dominant follicle in response to the $\mathrm{GnRH}$ analogue suggests that there is an adequate pituitary store of $\mathrm{LH}$ that can induce ovulation. Furthermore, Wise (1990) demonstrated, in postpartum ewes, that resumption of pulsatile $\mathrm{LH}$ release paralleled changes in pulsatile $\mathrm{GnRH}$ secretion. Thus the negative effect of suckling on reproductive function appears to act to a greater extent at the hypothalamic rather than at the pituitary level, by decreasing pulsatile secretion of $\mathrm{GnRH}$. However, since the precise role of $\mathrm{GnRH}$ in stimulating $\mathrm{LH}$ synthesis is unclear, definitive conclusions cannot be drawn. In cows, the content of $\mathrm{LH}$ in the anterior pituitary gland decreases during gestation (Nalbandov and Casida, 1940), remains low during the early postpartum period (days 1 and 15 post partum; Nett et al., 1988) and gradually increases to values similar to those present in cyclic animals by day 30 post partum (Moss et al., 1985; Nett et al., 1988). Our results indicate that there is sufficient releasable $\mathrm{LH}$ to induce ovulation 14-16 days post partum. Wettemann et al. (1982) demonstrated that $\mathrm{GnRH}$ can induce an LH surge in postpartum beef cows, which supports our evidence that there is in fact adequate $\mathrm{LH}$ available for release provided that the appropriate $\mathrm{GnRH}$ signal occurs.

A number of factors affect $\mathrm{LH}$ secretion and ovarian function in postpartum cows, including body condition score and plane of nutrition (Wright et al., 1992), energy balance (Canfield and Butler, 1990) and suckling frequency (Lamming et al., 1982). In beef heifers, Murphy et al. (1991) demonstrated that the plane of nutrition affected the diameter of the dominant follicle: heifers on a high feed intake had significantly larger dominant follicles than did heifers on maintenance or below maintenance diets. In addition, the proportion of beef cows in low body condition at 9 weeks post partum with large oestrogenic follicles was significantly decreased compared with controls (Prado et al., 1990). The oestrogen content of follicles classed as oestrogen active in beef heifers that were rapidly losing weight was significantly decreased compared with the oestrogen content of similar follicles in heifers gaining weight (Spicer et al., 1991), suggesting that nutritionally induced changes in gonadotrophins also affect the physiological function of dominant follicles. Thus, body condition of the cows and energy balance are likely to affect the resumption of follicular development and the ovulatory response to $\mathrm{GnRH}$.

Monitoring of ovarian follicles using ultrasound does not give precise information on the oestrogenic activity or functional state of the follicle. In this study, we arbitrarily defined a decrease in size of $\geq 3.0 \mathrm{~mm}$ as an indicator of atresia of a dominant follicle. There was no difference in the ability of the first dominant follicle to ovulate or form a normal corpus luteum following GnRH injection in the declining phase of development compared with the growing-plateau phase of development, suggesting that either a dominant follicle which decreased in size by $\geq 3 \mathrm{~mm}$ is not atretic or a dominant follicle in the early stages of atresia can still ovulate and form a corpus luteum. It is unclear which of these options is correct but, since atresia is a gradual process resulting in slow degeneration of granulosa cells, the follicle may ovulate, even after degeneration has commenced. However, there was a variable response in the GnRH-D group in which four cows failed to ovulate (in one cow the dominant follicle luteinized and in the other three the dominant follicle regressed normally). This variation may be attributable to the dominant follicles being at different stages of atresia, which are undetectable by ultrasound scanning, at the time of GnRH treatment. Further work is necessary to correlate the size of the declining dominant follicle with oestrogen activity of the follicle and rate of development of pycnotic granulosa cells and thus define the state of atresia of follicles based on ultrasound examination.

The occurrence of short cycles after first ovulation in this study was not surprising, as short cycles occur spontaneously before oestrus in prepubertal heifers (Berardinelli et al., 1979) and ewe lambs (Keisler et al., 1983), and following parturition in cows and ewes (Lamming et al., 1981; Sharpe et al., 1986). Follicular development during short cycles is associated with the development of a single dominant follicle (Savio et al., 1990). Postpartum dairy cows ovulating before day 10 had a low incidence of short cycles; those ovulating between days 10 and 20 had short, normal and long cycles and those ovulating 20-40 days post partum had a high incidence of short cycles (Savio et al., 1990). This finding suggests that beef cows ovulating in response to $\mathrm{GnRH}$ treatments on either $16.1 \pm 0.8$ (GnRH-G) or $18.0 \pm 1.1$ (GnRH-D; responders) days post partum might have had a lower incidence of short cycles compared with the controls ovulating $27.1 \pm 2.5$ days post partum. However, there was no difference in the incidence of short cycles between treatments, suggesting that short cycles are associated with first ovulation at about day 16-30 in postpartum beef cows. Further work is necessary to overcome the occurrence of short cycles and lack of oestrus in response to GnRH-induced ovulation. A potential approach would be to incorporate progesterone treatment in conjunction with $\mathrm{GnRH}$ administration (when a dominant follicle is present).

In conclusion, this study demonstrates that in beef suckler cows exogenous $\mathrm{GnRH}$ will consistently induce ovulation of the first dominant follicle that develops within 10-15 days post partum. In addition, this study lends support to the hypothesis that anovulation in the early postpartum period is due to inadequate LH secretion (Roche et al., 1992). Use of GnRH requires

Downloaded from Bioscientifica.com at 04/26/2023 07:37:57 AM 
ultrasound scanning of dominant follicles, but the problems of lack of expression of behavioural oestrus and high incidence of short cycles need to be overcome.

This study was supported by the National Agricultural and Veterinary Biotechnology Programme of BioResearch Ireland and University College Dublin (UCD). The authors acknowledge Hoechst Ireland Ltd for the supply of Receptal and Clonatec Ltd, Paris for the supply of monoclonal antiserum for the progesterone radioimmunoassay. The authors thank D. Harrington (Teagasc) for advice on statistical analyses, $S$. McDonnell (UCD) for assistance with progesterone assays and the staff of Lyons Research Farm (UCD) for care of the animals.

\section{References}

Badinga L, Driancourt MA, Savio JD, Wolfenson D, Drost M, De La Sota RL and Thatcher WW (1992) Endocrine and ovarian responses associated with the first wave dominant follicle in cattle Biology of Reproduction 47 871-883

Berardinelli JG, Dailey RA, Butcher RL and Inskeep EK (1979) Source of progesterone prior to puberty in beef heifers Journal of Animal Science $\mathbf{4 9}$ $1276-1280$

Braden TD and Conn PM (1991) Gonadotropin-releasing hormone and its actions Canadian Journal of Physiology and Pharmacology 69 445-458

Britt JH, Kittok RJ and Harrison DS (1974) Ovulation, estrus and endocrine response after GnRH in early postpartum cows Journal of Animal Science 39 915-919

Canfield RW and Butler WR (1990) Energy balance and pulsatile LH secretion in early postpartum dairy cattle Domestic Animal Endocrinology 7 323-330

Edwards S, Roche JF and Niswender GD (1983) Response of suckling beef cows to multiple, low-dose injections of $\mathrm{Gn}-\mathrm{RH}$ with or without progesterone pretreatment Journal of Reproduction and Fertility 69 65-72

Fonseca FA, Britt JH, Kosugiyama M, Ritchie HD and Dillard EU (1979) Ovulation, ovarian function, and reproductive performance after treatments with $\mathrm{GnRH}$ in postpartum suckled cows Theriogenology 13 171-181

Fortune JE (1986) Bovine theca and granulosa cells interact to promote androgen production Biology of Reproduction 35 292-299

Keisler DH, Inskeep EK and Dailey RA (1983) First luteal tissue in ewe lambs: influence on subsequent ovarian activity and response to hysterectomy Joumal of Animal Science 57 150-156

Lamming GE, Wathes DC and Peters AR (1981) Endocrine patterns of the postpartum cow Journal of Reproduction and Fertility Supplement 30 155-170

Lamming GE, Peters AR, Riley GM and Fisher MW (1982) Endocrine regulation of postpartum function Current Topics in Veterinary Medicine and Animal Science 20 148-172

Mawhinney S, Roche JF and Gosling JP (1979) The effects of oestradiol benzoate $(\mathrm{OB})$ and gonadotrophin releasing hormone $(\mathrm{GnRH})$ on reproductive activity in beef cows at different intervals post partum Annales de Biologie Animale, Biochimie et Biophysique 19 1575-1587

Moss GE, Parfet JR, Marvin CA, Allrich RD and Diekman MA (1985) Pituitary concentrations of gonadotropins and receptors for GnRH in suckled beef cows at various intervals after calving Journal of Animal Science 60 285-293

Murphy MG, Boland MP and Roche JF (1990) Pattern of follicular growth and resumption of ovarian activity in postpartum beef suckler cows joumal of Reproduction and Fertility 90 523-533
Murphy MG, Enright WJ, Crowe MA, McConnell K, Spicer LJ, Boland MP and Roche JF (1991) Effect of dietary intake on pattern of growth of dominant follicles during the oestrous cycle in beef heifers Journal of Reproduction and Fertility 92 333-338

Myers TR, Myers DA, Gregg DW and Moss GE (1989) Endogenous opioid suppression of release of luteinizing hormone during suckling in postpartum anestrous beef cows Domestic Animal Endocrinology 6 183-190

Nalbandov A and Casida LE (1940) Gonadotropic action of pituitaries from pregnant cows Endocrinology 27 559-564

Nett TM, Cermak D, Braden T, Manns J and Niswender G (1988) Pituitary receptors for $\mathrm{GnRH}$ and estradiol, and pituitary content of gonadotropins in beef cows. II. Changes during the postpartum period Domestic Animal Endocrinology 5 81-89

Peters AR, Pimentel MG and Lamming GE (1985) Hormone responses to exogenous GnRH pulses in post-partum dairy cows Joumal of Reproduction and Fertility 75 557-565

Prado R, Rhind SM, Wright IA, Russel AJF, McMillen SR, Smith AJ and McNeilly AS (1990) Ovarian follicle populations, steroidogenicity and micromorphology at 5 and 9 weeks post partum in beef cows in two levels of body condition Animal Production 51 103-108

Riley GM, Peters AR and Lamming GE (1981) Induction of pulsatile LH release and ovulation in postpartum cyclic beef cows by repeated small doses of GnRH Journal of Reproduction and Fertility 63 559-565

Roche JF, Crowe MA and Boland MP (1992) Postpartum anoestrus in dairy and beef cows Animal Reproduction Science 28 371-378

Ronayne E and Hynes N (1990) Measurement of plasma progesterone by extraction and non-extraction radioimmunoassays Irish Journal of Agricultural Research 29 109-115

Savio JD, Boland MP, Hynes N and Roche JF (1990) Resumption of follicular activity in the early postpartum period of dairy cows Journal of Reproduction and Fertility 88 569-579

Schallenberger E (1985) Gonadotrophins and ovarian steroids in cattle. III. Pulsatile changes of gonadotrophin concentrations in the jugular vein post partum Acta Endocrinologica 109 37-43

Sharpe PH, McKibbin PE, Murphy BD and Manns JG (1986) First postpartum corpora lutea in ewes which lamb in the breeding season Animal Reproduction Science 10 61-74

Silveira PA and Williams GL (1991) Effects of 'own' versus 'alien' suckling on luteinizing hormone secretion and interval to first ovulation in early postpartum, anestrous beef cows Journal of Animal Science 69 (Supplement 1) 417, Abstract

Snedecor GW and Cochran WG (1980) Statistical Methods (7th edn), pp 21.5-237. lowa State University Press, Ames

Spicer LJ, Enright WJ, Murphy MG and Roche JF (1991) Effect of dietary intake on concentrations of insulin-like growth factor- 1 in plasma and follicular fluid, and ovarian function in heifers Domestic Animal Endocrinology 8 431-437

Walters DL, Short RE, Convey EM, Staigmiller RB, Dunn TG and Kaltenbach CC (1982) Pituitary and ovarian function in postpartum beef cows. III. Induction of estrus, ovulation and luteal function with intermittent small-dose injections of GnRH Biology of Reproduction 26 655-662

Wettemann RP, Beck TW, Turman EJ and Hintz RL (1982) Endocrine response of postpartum anestrous beef cows to GnRH or PMSG Theriogenology 18 $599-613$

Wise ME (1990) Gonadotropin-releasing hormone secretion during the postpartum anestrous period of the ewe Biology of Reproduction 43 719-725

Wright IA, Rhind SM, Whyte TK and Smith AJ (1992) Effects of body condition at calving and feeding level after calving on $\mathrm{LH}$ profiles and the duration of the postpartum anoestrous period in beef cows Animal Production 55 41-46 